\title{
RISING GEO-STRATEGIC COMPETITION BETWEEN UNITED STATES AND CHINA: A CASE STUDY OF SOUTH ASIA IN THE EMERGING GLOBAL ORDER
}

\author{
Prof. Dr. Amir Ahmed Khuhro \\ Institute of International Relations, Shah Abdul Latif University, Khairpur, Sindh, Pakistan \\ E.mail: amir.khuhro@salu.edu.pk
}

\begin{abstract}
The South Asian region is characterized by the versatile nation state system with having greater economic prospects and has a unique rank in the world. United States and China are not only the sheer competitors across the globe but are also the major contenders of South Asian geo-strategic, political and economic affairs. Their intensifying interests in the region are not only due to the emerging global security architecture but also because of the geo-strategic significance of the South Asian region. China seems vulnerable to the United States military presence in the region and China's rapid economic growth and piling up of military muscle seemingly intent to counter the United States in the region. China, through its economic and military advancements has positioned itself as the principal regional power and further intends to accomplish its national interests by strengthening security and defence requirements. The presence of the other major regional powers like Pakistan and India also amplify the geographical prominence and the US-China interest in South Asia put it in the forefront due to which the South Asian region strategically have become much more interested during the emerging world order for both US and China, United States also regards the rise of China as a vital global participant and invites it to peacefully play its role in the modification of the future world order in this connection this paper will highlight the both super powers policy of context of power transition contentment and counter-contentment either the United States still has the strategy to contain China and if it is so, how China is counter-containing the United States to emerge as a global power politics towards south Asian region.
\end{abstract}

Keywords: Contentment, Dominancy, Emerging, Geo-strategic, Global Order, Power Politics, South Asia, Transition.

\section{INTRODUCTION}

During the Cold War era, the United States had adopted the strategy to contain the communist China and its rise in the region. In spite of the U.S. containment policy, China has achieved a desirous economic strength, political reputation and strategic objectives in the region and is now the rising global power after the Unite States. In the wake of the growing influence of China in the South Asia, the United States is seemingly seeking to strengthen its relations with certain allies to counter China's rise, for the purpose India is comparatively larger market for the United States and is a potential powerful regional ally to counterbalance China. On the other hand China is investing in Pakistan through OBOR and New Silk Road to boost its relationships with its staunch ally. 
China, as the second largest global power is arguably to balance the United States and seemingly becoming successful to redesign the global architecture to multipolar order from the contemporary world order. After unifying its comprehensive national power China is continuously putting emphasis on to unify its mainland and maritime boundaries. After assuming the role of a global power, China will put its weight over the international community to become a vital stakeholder of the global affairs. China has emerged as regional major power which the United States views is not in its interest in the region. In order to secure its global interests, the United States brings to use all the measures including military, diplomatic, and economic means through the alliance building and along with the manipulation of global institutions and some other notable strategies such as containment, engagement and encirclement policies (Karim, 2012, pp.176-177). The United States during the Obama administration adopted the rebalance policy to counter China globally and especially in the region, China may follow the suit to ensure its national interests in the region.

Alongside the economic reforms and achieving certain preeminent rank in the global economic order, China is revolutionizing and modernizing its military muscle. The rising China is offering opportunities as well as threats for the regional countries. The non-intervention policy in the internal affairs of the other states and the peaceful rise of China however indicates that China brings more opportunities for the neighbouring countries but the possibilities of a potential hard power in contrast to its adversaries especially against the regional contenders in case of the threat to the core national interests of China cannot be disregarded (Karim, 2012, p.177).

The realist perspective about the human nature or states is pessimistic and cyclic like human possibilities. The realism views that conflict is inevitable, and the realists are at the same time sceptical of the peace and cooperation between and among human and states as they inherent competition. The prospects of contradictory events those took place in the past among the states can potentially be happened in the future. The undesirable incidents are supposed to be repeatedly occur on the global stage in the absence of a central power to exercise certain set of strict laws and in the presence of the balance of power or other measures like diplomacy and economic relations. Secondly realism emphasizes that in the international system states seek to gain more power and calculate their interests in terms of power in relationship with other states.

However some of the countries will backing China contrary to the United States' regional engagements which culminates in the multi-dimensional circumstances of both the major powers bilateral and multilateral relations (Sutter, et al., 2013, pp.3-4). The United States has to face many challenges like to avoid any confrontation with China in the region and it also has to ensure its support for its allies. Its allies and friendly countries in the region, who undoubtedly will inquire the United States to assure its presence in order to minimize the China threat. On the other hand China will view this kind of relations of the United States with the regional countries as an act of containment.

To overcome such issues China needs to address its peaceful rise and put up with economic growth to come up with the United States (Sutter, et al., 2013, p.4). Achieving economic realization, China will certainly pile up its military. China's internal matters like nationalism, political system along with uncertain future intentions increase in the suspicions among the neighbouring countries.

In the view of liberalism, the states are always cooperative in the economic interdependence while at the same time the realism illustrate the states as competitive to one another. The United States, China, and Japan are the major regional contenders, where India is also an aspirant and competitor to be not only a regional major power but also is desirous of becoming a global giant posing China a challenge in the region. The rise of China and India remind us of to somehow the emergence of the Germany and the United States in the nineteenth and twentieth centuries respectively which transformed the geopolitical scenarios. Certain impacts have already been felt in the region and will certainly effect the global order in pursuit of the rise of these two states (Karim, 2012, p.178). China and India have their unresolved tension over border and even after resolving such differences any tragic event between these two cannot be precluded. China and India are the sheer competitors in the region in view their aspiration of regional and world powers.

The United States has also formed or forming alliance with India, Japan, Australia and South Korea in order to contain China's rise. China has historical relations with Russia in the region and beyond to counter-contain the United States. China is also building and modernizing its military. Apart from the containment, countercontainment, alliance and alignment formation in the region, both the United States and China are also participating and showing their interests to participate in the regional organizations having observer status in SAARC and their engagement with the other regional economic and security organizations. Another core issue faced by the regional integration is due to the India-Pakistan rivalry which is further manipulated by the greater powers to form blocks in the region. 


\section{US-CHINA RELATIONS IN THE CONTEXT OF POWER TRANSITION}

The power transition theory elaborates the international system in a manner that is different from, and also rejects the assumptions presented by the realist viewpoint about the international system (Organski and Kugler, 1958, pp.172-173). The power transition theory explains the structure of the international system is not anarchical and is similar in hierarchy to the governing body of a domestic political system. Each state adjusts itself in that international order according to its power and proclaims specific influence, competes and cooperates with other nations for gaining of resources (Organski and Kugler, 1958, pp.172-173).

The struggle between the rising and the dominant states culminate in the alteration of the global order or the formation of a new leadership on the world stage (Organski and Kugler, 1958, pp.172-173). The power transition theory interprets some significant features about the nature of a state those have intense affects over the international arena. The economic growth of a rising power increases in the national power of the state. The rising power, due to its economic development brings certain impacts over the international system and specifically over the dominant power (Lia, 2011, p.5). The past has witnessed strenuous relationships between the rising and the dominant power when there is a conceivable transformation in the status quo of the international order.

Figure 1. The Logic of War and Peace

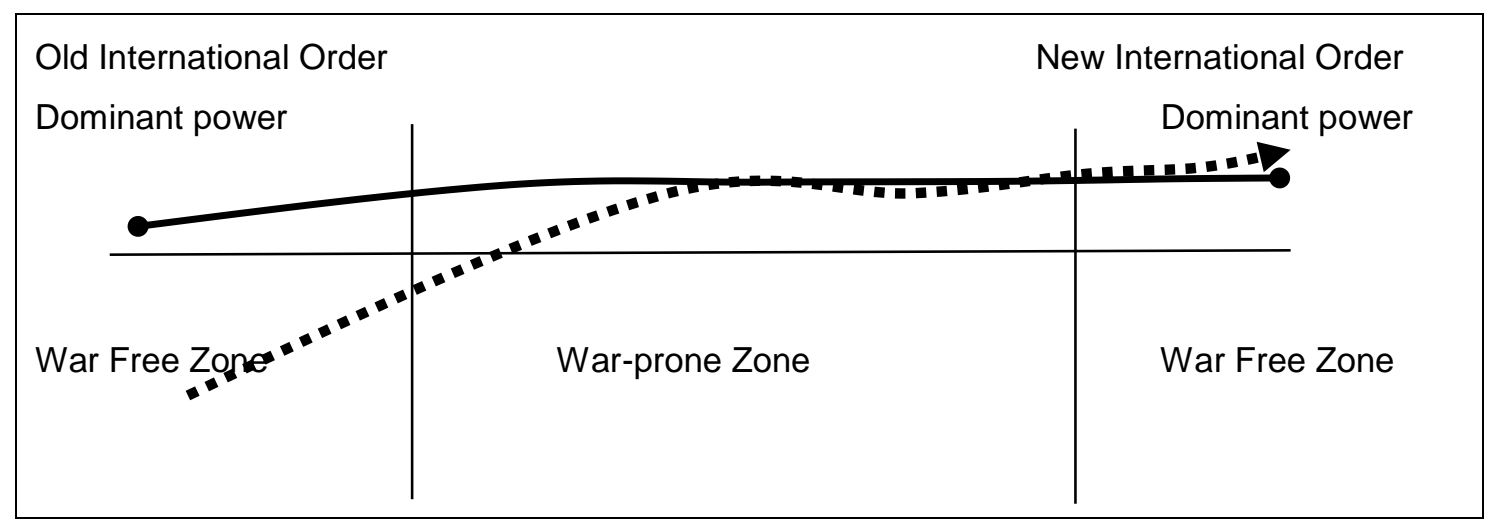

(Lai, 2011, p. 7)

The recent growing relations between the United States and China will consequently be conflicting through the interpretation elaborated by the power transition theory. The power transition theory converges the attention to the conflicts happened in the past during power transferals from a state to the other, for instance the conflicting power shift between Athens and Sparta in the Peloponnesian War and from Spain to Netherlands, to France and from France to Britain and lastly Britain and the United States became the governing powers followed by the rise and defeat of the Germany and Japan in Second World War.

The dissatisfaction with the current order, its capabilities and determination to restructure the contemporary international order put China on the top ranking amongst the competitors of the United States (Lia, 2011, pp.18-19). At present not only China impinges a potential challenge to the United States' led unipolar order but there are other competing major powers like India, Brazil, and the European Union. The resurgence of Russia over the global stage and the military modification of Japan cannot be unnoticed. But among all these states, China is believed to be the leading contender of the United States.

Apart from the renunciations by the Chinese officials, the prospects of a future global leadership for China seems lesser but the rise of China will inevitably alter the existing global order. China has unresolved differences and rivalries with the countries like India and Japan but the U.S.-China relationships somehow are not the same and their power transition on the world stage is due to the restructuring of the world order and for the global leadership. The Chinese leaders have their emphasis to avoid any confrontation with the United States and to peacefully raise the Chinese economy. (Lia, 2011, p.77)

The United States also regards the rise of China as a vital global participant and invites it to peacefully play its role in the modification of the future world order. China, seemingly will not engage in conflicts with the United States before becoming as dominant as the United States (Lia, 2011, pp.83-84). The power transition between the United States and China may not be harmful to each other in terms of war because both the countries are well acknowledged about the consequences of a possible contest. The communication at countries level, the strategic and economic dialogues formed in 2005 for instance, also assist both countries to address the distrust. 


\section{US-CHINA RELATIONS: CONTAINMENT AND COUNTER-CONTAINMENT}

During the Obama period in office the strategic relationship with the Asian countries were revitalized keeping in view the significance of the region. The United States has wide-ranging interests and is militarily, economically and diplomatically present in this strategically vital region since the Second World War. Asia, again retracted the United States consideration during the then U.S. President Obama administration in 2011-12 and to peacefully engage with China the United States reordered its military initiatives to economic and other diplomatic measures (Sutter, et al., 2013, p.1).

The United States is intended to augment bilateral relations with regional allies including China (Sutter, et al., $2013, p .2)$. The policy of rebalance introduced by the Obama administration is viewed by the Chinese as containing the economic upsurge of China. However, the military, economic and diplomatic reengagement in the Asian pacific after a decade of military operations through the rebalance policy is a strong notion that the United States will still compete for its national interests in the region.

China seems vulnerable to the United States military presence in the region and China's rapid economic growth and piling up of military muscle seemingly intent to counter the United States in the region. China, through its economic omnipotence and military advancements has positioned itself as the principal regional power and further intends to accomplish its national interests by strengthening security and defence requirements. The growing United States' interest, interference, alliance making and other strategic operations in the regions enhance in the suspicions of China perceiving to take counter actions in the region and beyond (Bergerson, 2016, 3-4). The foremost challenge to China is to safeguard the mainland China including Taiwan and South China Sea. While defending its core national interests the use of hard power by China against the perceived threat of the United States presence will certainly bring adverse implications for the entire regional stakeholders.

The United States is vibrant to secure her own and its allies' interest in the region, participating in the regional trade agreements and taking measure to provide security to the allies thwarted by the rising China. The balancing acts of the United States make increase in the sensitivity of China creating more differences. Simultaneously China also gives the impression to be unwilling to collaborate with the United States in the region. To counter the United States' engagements, China is participating and promoting the regional countries to eliminate or minimize the role of the United States in the region (Sutter, et al., 2013, p.13).

In the field of military the strategy of balancing while engagement and shaping policies have been adopted in economic and political spheres by the European countries and the United States since long in relationship with the Asian countries. Certain polices by the Western countries are still in practice with China to embolden China in investing in the ongoing projects. The United States is seemed to revise its Cold War strategy of containment to balance China rise economically, politically and militarily in the region and beyond (Leonard, 2016, p.2).

\section{ASIA AS THE IMMINENT ECONOMIC POWER IMPACTING GLOBAL ORDER}

The Asian region was colonised and governed by the Europe for about two centuries and for another hundred years the region was strategically dominated by the United States. While emphasizing the same reality and stressing the significance of the Asia, former US secretary, Hillary Clinton stated that it is quite distinct that the future strategic and economic centre of gravity of the world will be the Asia Pacific region from the Indian continent to the American shores (Kapila, 2012, p.2). The contemporary economic build-up of the Asian countries has contributed to the global economic rise and at the same time it turned the power in her favour. Currently the Asian region has economically overwhelmed the United States including other western economic powers that make available a global influence to Asia. In the year 2011-12, the United States may have officially recognised the shift of global power to Asia.

The regional economic integration, building and promoting the regional institutions could strengthen the role of Asia in transforming the existing world order. The ASIAN is promoting to enhance economic interdependence among the associated countries paving the way for a multilateral order in the region. On the other hand China is also taking concrete measures by investing in projects, New Silk Road and One Belt One Road for instance, which help to interconnect not only the Asian countries but also the entire region to Eastern Europe and the Central Asia (Horizons, 2015, p.3). On July 27, 2012, the opening remarks during the first U.S.-China Strategic and Economic Dialogue, at Washington D.C., of the then U.S. President Barack Obama were,

"We can't predict with certainty what the future will bring, but we can be certain about the issues that will define our times. And we also know this: The relationships between the United States and China will shape the $21^{\text {st }}$ century......" 
It appears certain from the given statement that the United States is well acknowledge of its declining global supremacy and that it cannot deal with the global matters without the assistance of a rising China. The rising China will certainly put its weight to restructure the United States led unipolar order of the world (Lai, 2011, p.1). The U.S.-China relations are complex in nature and comprised of cooperation and competition.

The Asian countries especially China and India are in quest of establishing extra-territorial strategic stations. Their competence of self-relying security structures and military capabilities will make the balance more complex (Horizons, 2015, p.3). The technological advancement and military modernization of the Asian countries will potentially lessen the United States regional influence and they may need to form their multifaceted security cooperation.

The anticipated shift of global power to Asia indicates the decline of the contemporary world order and the end to the era of the United States' leverage in the international affairs. As many of the Asian countries are rising economically will turn the current unipolar order to multi-polarity (Kapila, 2012, pp.2-3). The South Asian region will have profound effects and influence on the global security architecture through its rising economy and modernizing military and technology. Their boosting economies will assist them to invest and strengthen their security capabilities, the smaller regional countries will potentially be deterred by the huge economic and defence capabilities of China and India. In the coming decade China and India will try to promote their navies by developing bases beyond their borders. To counter the United States encirclement, China will maximise its military capabilities in the region and globally as well. In order to counter the United States, China may follow suit to counter weigh the continued U.S. military presence in the region and its relenting operations in the sea. A multipolar regional order will emerge due the circumstances that will certainly have profound effects over the global architecture.

\section{REGIONAL IMPLICATIONS AND OPPORTUNITIES}

Through its economic growth and political prevalence the Asia Pacific has diverted the global power towards its centre which is acknowledge as 'the global shift of power to Asia'. The Asia Pacific has never lost its significance to the United States, it remained a vital region and a focus of the United States military power since the Cold War era. Among the many reasons there are two main strategic and military reasons, why this region has its importance for the United States. First the United States has its military allies among them are Japan, Taiwan, South Korea and Philippines and secondly the United States has exercised the region to contain communism during the Cold War era There are no rising major concerns for the United States by the rise of other Asian military powers like India and Japan. Japan is already a dependable ally and India is persuaded by the United States to strategically counter weight China. (Kapila, 2012, p.4)

The recent circumstances envisage that China will gain more as compare to all other stakeholders in region by capturing market opportunities, finding new strategic allies and strengthening its influence. Japan and India may loss the regional markets, strategic influence and political position against China and a decline in the United States' leadership may occur due the rapid economic growth of China. The situation between China and Russia will be almost the same in Central Asia. This shift will encourage China to form or bring enormous amendments to the existing institutions and their norms (Leonard, 2016, pp.2-3). The global order is ultimately to be transformed because of the growing political and economic might of the China.

China's remarkable economic growth, military modernization, technological up gradation tended to shift the global power to Asia. . Consequently a new Cold War is ostensibly to be started between the United States and China as China is the foremost country in the region that can edge and challenge the United States' interests in the military and economic spheres (Leonard, 2016, pp.2-3). Currently China's economic growth is putting certain profound effects over the regional economies. According to an estimated data by the IMF, if there is a one percent decrease in the China's economic growth there is 0.3 percent drop in the growth in Asia, 0.6 percent in East Asia and a higher decline up to 0.7 percent in that of the ASEAN countries. The decrease in the Chinese stock exchange in the year 2016, caused global spill over effects (Rediker, Elizabeth, Levi, 2016).

In the year 2014, China's trade with the United States reached a sum of US\$ 590.7 billion becoming the second largest partner of the United States. The same year China had the largest trade partnership with South Korea and the ASEAN with a total trade volume of US\$290 billion and US\$366 billion respectively (Mahbubani, 2016). By economic measures China has took concrete steps to augment its relations with the region countries. Through the $21^{\text {st }}$ century Maritime Silk Road project, China is investing by funding to build infrastructure (Mahbubani, 2016).

Since last few years China is effectively on the track to normalise and improve its relations with the neighbouring nations through bilateral and multilateral trade ties and other diplomatic means. China's policies are generally sought by the Asian countries to be appropriate while persuading their mutual interests 
during bilateral relations with China and in the other regional organizations. The rise of China and its regional policies offer more opportunities while demanding lesser from the regional countries.

The simultaneous rise of Asian powers have paved the way to arrange a multipolar regional order. Due to the competence Asian countries have solely achieved to face the contemporary strategic challenges. Because of the internal political hostilities and military resentments, the regional countries however may not unite to the United States against the potential threat of China, as these countries are vibrantly participating in the regional economic cooperation. The scenario could impinge serious impacts over the United States' regional interests.

The ascending China is impacting the regional countries and the United States as well, rising China may now intensely focus on its maritime disputes in the South China Sea which is surely adding to the worries of the neighbouring countries and in the suspicion of the United States to be denied from the free access to these waters. These circumstances have increased in the United States interest to directly involve in these disputes to rebalance the ascendance of China. During the Obama administration the United States interfered and suggested a multilateral solution to the South China Sea. The United States is confronted by the economic downturn and other issues which may not let the United States to rebalance the China in the region. The declining political well and the shrinking of economic supremacy of the United States will assist China to gain more regional influence and a window of opportunity to strengthen its leadership role in the region.

The increase in the allocation of security budgets and by stationing the United States military in the region in order to contain or rebalance the ascendance of China, a forecasted emergence of a New Cold War between the United States and China is seemed inevitable. In 2011, the former United States President Obama mention that the United States taking financial measure along with other important means to maintain our military presence in the region to prevent a possible threat to the peace in the region.

\section{CONCLUSION}

The rebalance, containment or engagement strategies of the United States are seemingly because of the reality that the United States do not embracing the emerging global role of a rising China. The United States might be conscious of being replaced by another power and is seemed reluctant to collaborate with China on the world stage. The United States should realise the growing international prestige of China and should regard its emerging role and contribution regionally and globally. Both the countries need to address the global challenges and to sort out global issues in collaboration. Since long the United States has adapted certain strategies for the purpose to hinder the rise of China and to contain it globally from thwarting the unipolar moment of the United States. Those strategies could not assist the United States to halt the current economic accomplishment and global stature of China. The rising economies and modernizing militaries of South Asia has attracted the United States attention to stay engage in the regional affairs. It seems that the United States will adopt its Cold War Strategy of 'Containment' or to rebalance the rise of China, the reason why the United States is getting closer to India to supposedly counter weigh China's rise. China is countercontaining the United States by allying to Russia and Pakistan. What will be the consequences of the relations it depends on competition and cooperation between the United States and China.

\section{REFERENCE LIST}

Bergerson, Kristien. (2016). China's efforts to counter U.S. forward presence in the Asia Pacific. U.S.-China Economic and Security review Commission. March 15, 2016. pp. 3-4.

Horizons. (2015). The future of Asia: implication for Canada. Canada: Geostrategic cluster finding. p. 3.

Kapila, Subhash. (April 17, 2012). The global power shift to Asia: geostrategic and geopolitical implications. Al Jazeera Centre for Studies. p. 2-4.

Karim, Mohd Aminul. (2012). Strategic vision of China and the United States in South Asia and beyond. The Korean Journal of Defense Analysis Vol, 24, No. 2, June 2012, pp. 176-77.

Leonard, Mark. (January, 2016). Geo-economics with Chinese characteristics: how China's economic might is reshaping world politics. Geneva, Switzerland: World Economic Forum, pp. 2-3.

Lia, David. (December, 2011). The United States and China in power transition. Washington D. C.: Strategic Studies Institutes. p. 1-19. 
Mahbubani, Kishore. (January, 2016). China's role in Asia Pacific. Geneva, Switzerland: World Economic Forum, Geo-economics with Chinese characteristics: how China's economic might is reshaping world politics.

Organski and Kugler, J. (1958). The power transition: a retrospective and prospective evaluation. pp. 172-73.

Rediker, Douglas. E. Elizabeth, Levi, Michael. (January, 2016). The geo-economic implications of China's changing growth strategy. Geneva, Switzerland: World Economic Forum, Geo-economics with Chinese characteristics: how China's economic might is reshaping world politics. January, 2016.

Sutter, Brown, et al. (2013). Balancing acts: the U.S. rebalancing and Asia-Pacific stability. Washington D.C.: Sigur Center for Asian Studies. pp. 1-13. 